\title{
Chronic Myeloid Leukemia in a Patient with Hepatitis B Virus Infection: A Case Report
}

\author{
Yousef Mohammed Ali Hailan ${ }^{a}$ Deena Mudawi ${ }^{b}$ Mohamed A. Yassin ${ }^{b}$ \\ aInternal Medicine Department, Hamad General Hospital, Hamad Medical Corporation, \\ Doha, Qatar; ' National Center for Cancer Care and Research, Hamad Medical Corporation, \\ Doha, Qatar
}

\section{Keywords}

Hepatitis B · Hepatitis B virus reactivation - Chronic myeloid leukemia - Imatinib - Tyrosine kinase inhibitor

\begin{abstract}
Chronic myeloid leukemia $(\mathrm{CML})$ is a myeloproliferative disorder diagnosed by demonstrating the Philadelphia chromosome $(\mathrm{Ph})$ or the $\mathrm{BCR}-\mathrm{ABL}$ fusion gene. Tyrosine kinase inhibitors (TKIs) are the standard of therapy. There are increasing reports of hepatitis $B$ virus reactivation $(\mathrm{HBVr})$ in patients on this treatment. We report a case of a 46 -year-old male patient diagnosed to have $C M L$ in the chronic phase and resolved hepatitis $B$ infection. He was treated with imatinib as upfront therapy for $C M L$ and with lamivudine as prophylaxis against HBVr. The patient tolerated both treatments well with no adverse effects. The aim is to address the deficiencies in the literature in regard to managing these patients, prevention, and follow-up.

(C) 2021 The Author(s).

Published by S. Karger AG, Basel
\end{abstract}

\section{Introduction}

Chronic myeloid leukemia (CML) is a malignant clonal disorder of hematopoietic stem cells and is one of the myeloproliferative disorders [1]. Revealing the Philadelphia chromosome (Ph) or the BCR-ABL fusion gene, by cytogenic or molecular analysis studies, is the standard diagnostic approach [2]. The management of $\mathrm{Ph}$ chromosome-positive and BCR-ABL1-positive CML has undergone a profound evolution with the tyrosine kinase inhibitors (TKIs) [3]. Currently, there are 5 TKIs approved by the FDA for the treatment of CML, including imatinib, dasatinib, nilotinib, bosutinib, and ponatinib [4]. 


\section{Case Reports in Oncology}

Table 1. Admission laboratory investigations showing marked leukocytosis

\begin{tabular}{l|l}
\hline Case Rep Oncol 2021;14:1004-1009 \\
\hline DOI: 10.1159/000516747 & $\begin{array}{l}\text { @ 2021 The Author(s). Published by S. Karger AG, Basel } \\
\text { www.karger.com/cro }\end{array}$ \\
\hline
\end{tabular}

Ali Hailan et al.: CML in a Patient with HBV Infection

\begin{tabular}{|c|c|c|}
\hline Lab test & Value & Normal range \\
\hline WBC & $96.3 \times 10^{3} / \mu \mathrm{L}$ & $4.0-10.0$ \\
\hline RBC & $4.4 \times 10^{6} / \mu \mathrm{L}$ & $4.5-5.5$ \\
\hline Hgb & $14.3 \mathrm{~g} / \mathrm{dL}$ & $13.0-17.0$ \\
\hline Hct, \% & 44.6 & $40.0-50.0$ \\
\hline $\mathrm{MCV}$ & $101.6 \mathrm{fL}$ & $83.0-101.0$ \\
\hline $\mathrm{MCH}$ & $32.6 \mathrm{pg}$ & $27.0-32.0$ \\
\hline MCHC & $32.1 \mathrm{~g} / \mathrm{dL}$ & $31.5-34.5$ \\
\hline RDW-CV, \% & 15.3 & $11.6-14.5$ \\
\hline Platelet & $203 \times 10^{3} / \mu \mathrm{L}$ & $150-400$ \\
\hline MPV & $11.5 \mathrm{fL}$ & $7.4-10.4$ \\
\hline Absolute neutrophil & $49.1 \times 10^{3} / \mu \mathrm{L}$ & $2.0-7.0$ \\
\hline Lymphocyte $^{\#}$ & $9.6 \times 10^{3} / \mu \mathrm{L}$ & $1.0-3.0$ \\
\hline Monocyte & $4.8 \times 10^{3} / \mu \mathrm{L}$ & $0.2-1.0$ \\
\hline Eosinophil & $1.0 \times 10^{3} / \mu \mathrm{L}$ & $0.0-0.5$ \\
\hline Basophil & $1.93 \times 10^{3} / \mu \mathrm{L}$ & $0.02-0.10$ \\
\hline Neutrophil, \% & 37.0 & \\
\hline Lymphocyte, \% & 10.0 & \\
\hline Monocyte, \% & 5.0 & \\
\hline Eosinophil, \% & 1.0 & \\
\hline Basophil, \% & 2.0 & \\
\hline Bands, \% & 14.0 & \\
\hline Metamyelocytes, \% & 4.0 & \\
\hline Myelocyte, \% & 24.0 & \\
\hline Promyelocytes, \% & 2.0 & \\
\hline Blasts, \% & 1.0 & \\
\hline Urea & $4.9 \mathrm{mmol} / \mathrm{L}$ & $2.8-8.1$ \\
\hline Creatinine & $77 \mu \mathrm{mol} / \mathrm{L}$ & $62-106$ \\
\hline Sodium & $144 \mathrm{mmol} / \mathrm{L}$ & $136-145$ \\
\hline Potassium & $4.3 \mathrm{mmol} / \mathrm{L}$ & $3.5-5.1$ \\
\hline Chloride & $103 \mathrm{mmol} / \mathrm{L}$ & $98-107$ \\
\hline Bicarbonate & $27 \mathrm{mmol} / \mathrm{L}$ & $22-29$ \\
\hline Calcium & $2.43 \mathrm{mmol} / \mathrm{L}$ & $2.15-2.50$ \\
\hline Adjusted calcium & $2.41 \mathrm{mmol} / \mathrm{L}$ & $2.15-2.50$ \\
\hline Bilirubin total & $10 \mu \mathrm{mol} / \mathrm{L}$ & $0-21$ \\
\hline Total protein & $76 \mathrm{~g} / \mathrm{L}$ & $66-87$ \\
\hline Albumin & $41 \mathrm{~g} / \mathrm{L}$ & $35-52$ \\
\hline Alkaline phosphatase & $65 \mathrm{U} / \mathrm{L}$ & $40-129$ \\
\hline ALT & $19 \mathrm{U} / \mathrm{L}$ & $0-41$ \\
\hline AST & $19 \mathrm{U} / \mathrm{L}$ & $0-40$ \\
\hline Glucose & $3.9 \mathrm{mmol} / \mathrm{L}$ & $3.3-5.5$ \\
\hline
\end{tabular}




\section{Case Reports in Oncology}

Table 2. Hepatitis B panel revealing a resolved/past HBV infection

\begin{tabular}{l|l}
\hline Case Rep Oncol 2021;14:1004-1009 \\
\hline DOI: 10.1159/000516747 & $\begin{array}{l}\text { @ 2021 The Author(s). Published by S. Karger AG, Basel } \\
\text { www.karger.com/cro }\end{array}$ \\
\hline
\end{tabular}

Ali Hailan et al.: CML in a Patient with HBV Infection

\begin{tabular}{ll}
\hline Serology & Interpretation \\
\hline Hepatitis B surface antibody & Reactive \\
Hepatitis B surface antigen & Nonreactive \\
Hepatitis B core antibody IgM & Nonreactive \\
Hepatitis B core antibody IgG & Nonreactive \\
Hepatitis B antibody titers & 26.80 \\
\hline HBV, hepatitis B virus. & \\
\hline
\end{tabular}

Hepatitis B virus (HBV) infection is a major public health problem worldwide; roughly $30 \%$ of the world's population show serological evidence of current or past infection [5]. It can cause both acute and chronic diseases. The WHO estimates that in 2015, 257 million people were living with chronic hepatitis B infection and that HBV resulted in an estimated 887,000 deaths [6]. We report a case of CML in a patient with a past hepatitis B infection to shed light on the rare association and nondecisive guideline recommendations regarding the prevention of flaring of hepatitis B infection.

\section{Case Report/Case Presentation}

A 46-year-old Filipino male patient was admitted for asymptomatic COVID-19 infection after he was tested positive for SARS-CoV-2 PCR as part of routine screening for contact of a known case of COVID-19. He had no significant past medical and surgical histories, no known allergies, and was not on chronic medications. Other than working as a cook and occasional alcohol intake, family and social histories were unremarkable. Aside from splenomegaly, which was also confirmed by ultrasound abdomen to be $16.2 \mathrm{~cm}$, the rest of the physical examination was noncontributory.

On routine blood labs, CBC showed notable leukocytosis $\left(96.3 \times 10^{3} / \mu \mathrm{L}\right)$ with normal other parameters (shown in Table 1). Peripheral smear suggested CML. The diagnosis was confirmed by interphase fluorescence in situ hybridization showing BCR-ABL1, $t(9 ; 22)$ (q34; q11.2) positivity. More detailed testing revealed a BCR-ABL1 to ABL1 percentage ratio of $84 \%$ international scale (IS), and characterization was positive for an e14a2 BCR-ABL1 gene fusion by single-step reverse transcription-polymerase chain reaction. At this stage, the diagnosis was confirmed to be CML in the chronic phase.

Before starting the TKI, the patient was screened for HBV infection. Serologic markers were going with past HBV infection (reactive anti-HBc IgG and reactive anti-HBs) (shown in Table 2).

Initially, the patient was put on preventive measures against tumor lysis until confirmation of the diagnosis. Then, the patient was started on imatinib for CML chronic phase as well as on lamivudine as a prophylactic against flaring of the HBV infection.

Blood cells were closely monitored during the initial period of treatment, and the latest results are shown in Table 3. BCR-ABL1 levels were also monitored at diagnosis (84\% IS), 3 months ( $92 \%$ IS), and 6 months ( $3 \%$ IS). By the newest results, it was evident that the response to treatment is optimal, and the decision is to continue the same regimen with further followup of BCR-ABL1 levels at 12 months. The patient is doing well and did not experience side effects from the medications. 


\section{Case Reports in Oncology}

Table 3. Follow-up laboratory investigations at 6 months

\begin{tabular}{l|l}
\hline Case Rep Oncol 2021;14:1004-1009 \\
\hline DOI: 10.1159/000516747 & $\begin{array}{l}\text { @ 2021 The Author(s). Published by S. Karger AG, Basel } \\
\text { www.karger.com/cro }\end{array}$ \\
\hline
\end{tabular}

\begin{tabular}{|c|c|c|}
\hline Lab test & Value & Normal range \\
\hline WBC & $3.8 \times 10^{3} / \mu \mathrm{L}$ & $4.0-10.0$ \\
\hline $\mathrm{RBC}$ & $3.0 \times 10^{6} / \mu \mathrm{L}$ & $4.5-5.5$ \\
\hline $\mathrm{Hgb}$ & $11.3 \mathrm{~g} / \mathrm{dL}$ & $13.0-17.0$ \\
\hline Hct, \% & 31.5 & $40.0-50.0$ \\
\hline MCV & $104.0 \mathrm{fL}$ & $83.0-101.0$ \\
\hline $\mathrm{MCH}$ & $37.3 \mathrm{pg}$ & $27.0-32.0$ \\
\hline $\mathrm{MCHC}$ & $35.9 \mathrm{~g} / \mathrm{dL}$ & $31.5-34.5$ \\
\hline RDW-CV, \% & 14.6 & $11.6-14.5$ \\
\hline Platelet & $63 \times 10^{3} / \mu \mathrm{L}$ & $150-400$ \\
\hline MPV & $9.6 \mathrm{fL}$ & $7.4-10.4$ \\
\hline Absolute neutrophil & $2.1 \times 10^{3} / \mu \mathrm{L}$ & $2.0-7.0$ \\
\hline Lymphocyte $^{\#}$ & $1.4 \times 10^{3} / \mu \mathrm{L}$ & $1.0-3.0$ \\
\hline Monocyte & $0.2 \times 10^{3} / \mu \mathrm{L}$ & $0.2-1.0$ \\
\hline Eosinophil & $0.1 \times 10^{3} / \mu \mathrm{L}$ & $0.0-0.5$ \\
\hline Basophil & $0.02 \times 10^{3} / \mu \mathrm{L}$ & $0.02-0.10$ \\
\hline Neutrophil, \% & 54.5 & \\
\hline Lymphocyte, \% & 36.9 & \\
\hline Monocyte, \% & 6.0 & \\
\hline Eosinophils, \% & 2.1 & \\
\hline Basophil \% & 0.5 & \\
\hline Urea & $3.6 \mathrm{mmol} / \mathrm{L}$ & $2.8-8.1$ \\
\hline Creatinine & $86 \mu \mathrm{mol} / \mathrm{L}$ & $62-106$ \\
\hline Sodium & $141 \mathrm{mmol} / \mathrm{L}$ & $136-145$ \\
\hline Potassium & $3.2 \mathrm{mmol} / \mathrm{L}$ & $3.5-5.1$ \\
\hline Chloride & $106 \mathrm{mmol} / \mathrm{L}$ & $98-107$ \\
\hline Bicarbonate & $26 \mathrm{mmol} / \mathrm{L}$ & $22-29$ \\
\hline Calcium & $2.21 \mathrm{mmol} / \mathrm{L}$ & $2.15-2.50$ \\
\hline Adjusted calcium & $2.27 \mathrm{mmol} / \mathrm{L}$ & $2.15-2.50$ \\
\hline Bilirubin total & $8 \mu \mathrm{mol} / \mathrm{L}$ & $0-21$ \\
\hline Total protein & $70 \mathrm{~g} / \mathrm{L}$ & $66-87$ \\
\hline Albumin & $37 \mathrm{~g} / \mathrm{L}$ & $35-52$ \\
\hline Alkaline phosphatase & $85 \mathrm{U} / \mathrm{L}$ & $40-129$ \\
\hline ALT & $44 \mathrm{U} / \mathrm{L}$ & $0-41$ \\
\hline AST & $48 \mathrm{U} / \mathrm{L}$ & $0-40$ \\
\hline
\end{tabular}

\section{Discussion/Conclusion}

TKIs, since their introduction, have become a cornerstone in the treatment of CML in the chronic phase, and the initial choice is imatinib (branded or generic), dasatinib, and notilinib [7-9]. Imatinib was first used in 1998, and its effect is primarily through inhibition of proliferation and induction of apoptosis of the BCR-ABL1 oncoprotein $[8,10,11]$. It is widely available and economically cheaper in comparison with the other options. 
Hepatic toxicity is one among other reported side effects of imatinib and other TKIs in general. It can be self-limited and reversible upon discontinuation of the inducing agent, and it can be serious and fatal. $\mathrm{HBV}$ reactivation (HBVr) is increasingly recognized as an important adverse effect with an incidence approaching 10.8 per 100 person-years in a retrospective cohort study [4]. Most of the reported cases are triggered by the use of imatinib [12-16]. It remains unclear whether imatinib alone causes HBVr or other TKIs are underreported.

Several definitions have been proposed for HBVr based on virologic, serologic, or both criteria; a simple definition would be an increase in HBV replication usually associated with a rise in serum aminotransferase levels $[4,17,18]$. Although there are recommendations to screen for HBV infection before starting immune-suppressing medications, however, guidelines about the prevention of HBVr in the context of TKIs remain uncertain. Given a growing number of reports about HBVr among patients taking these medications, our patient was started on lamivudine based on physician preference as there is no consensus upon it.

A recent publication addressed the issue of follow-up in such a population, and we agree with the authors [4]. Baseline liver function tests were established before starting treatment and followed at 1 month, 3 months, and 6 months. Further monitoring is planned at 1 year. However, infections and reactivation of infections like hepatitis and tuberculosis [19] remain important unmet needs that require further studies. The weight of this case report is to boost awareness about deficiencies in the current literature and to open a discussion in addressing the risk of HBVr and the lack of guidance in terms of prophylaxis and monitoring.

\section{Acknowledgment}

The authors wish to show their gratitude to the Internal Medicine Residency Program and to Dr. Dabia Hamad Almohanadi for their scientific support.

\section{Statement of Ethics}

The case was approved by the Hamad Medical Corporation Research Center with Reference No. MRC-04-21-232. Written informed consent was obtained from the patient for publication of this case report and any accompanying images.

\section{Conflict of Interest Statement}

The authors have no conflicts of interest to declare.

\section{Funding Sources}

This study was funded by the Qatar National Library.

\section{Author Contributions}

Yousef Mohammed Ali Hailan and Mohamed A. Yassin performed writing and editing and gave final approval of the concept. Deena Mudawi performed editing and approved of the final version.

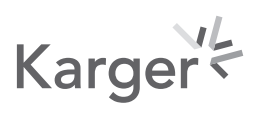




\section{Case Reports in Oncology}

\begin{tabular}{l|l}
\hline Case Rep Oncol 2021;14:1004-1009 \\
\hline DOI: 10.1159/000516747 & $\begin{array}{l}\text { @ 2021 The Author(s). Published by S. Karger AG, Basel } \\
\text { www.karger.com/cro }\end{array}$ \\
\hline
\end{tabular}

Ali Hailan et al.: CML in a Patient with HBV Infection

\section{References}

1 Sawyers CL. Chronic myeloid leukemia. N Engl J Med. 1999;340(17):1330-40.

2 Faderl S, Talpaz M, Estrov Z, O’Brien S, Kurzrock R, Kantarjian HM. The biology of chronic myeloid leukemia. N Engl J Med. 1999 Jul 15;341(3):164-72.

3 Baccarani M, Deininger MW, Rosti G, Hochhaus A, Soverini S, Apperley JF, et al. European LeukemiaNet recommendations for the management of chronic myeloid leukemia: 2013. Blood. 2013;122:872-84.

4 Atteya A, Ahmad A, Daghstani D, Mushtaq K, Yassin MA. Evaluation of hepatitis B reactivation among patients with chronic myeloid leukemia treated with tyrosine kinase inhibitors. Cancer Control. 2020;27: 1073274820976594.

5 Trépo C, Chan HL, Lok A. Hepatitis B virus infection. Lancet. 2014;384:2053-63.

6 Hepatitis B. Available from: https://www.who.int/news-room/fact-sheets/detail/hepatitis-b. Accessed 2021 Feb 8.

7 Höglund M, Sandin F, Hellström K, Björeman M, Björkholm M, Brune M, et al. Tyrosine kinase inhibitor usage, treatment outcome, and prognostic scores in CML: report from the population-based Swedish CML registry. Blood. 2013;122:1284-92.

8 Goldman JM. Initial treatment for patients with CML. Hematology Am Soc Hematol Educ Program. 2009;2009: 453-60.

9 Hughes TP, Ross DM. Moving treatment-free remission into mainstream clinical practice in CML. Blood. 2016; 128:17-23.

10 Druker BJ, Talpaz M, Resta DJ, Peng B, Buchdunger E, Ford JM, et al. Efficacy and safety of a specific inhibitor of the BCR-ABL tyrosine kinase in chronic myeloid leukemia. N Engl J Med. 2001;344(14):1031-7.

11 Cohen MH, Williams G, Johnson JR, Duan J, Gobburu J, Rahman A, et al. Approval Summary for Imatinib Mesylate Capsules in the Treatment of Chronic Myelogenous Leukemia. Clin Cancer Res. 2002;8(5):935-42.

12 Ikeda K, Shiga Y, Takahashi A, Kai T, Kimura H, Takeyama K, et al. Fatal hepatitis B virus reactivation in a chronic myeloid leukemia patient during imatinib mesylate treatment. Leuk Lymphoma. 2006;47:155-7.

13 Lakhani S, Davidson L, Priebat DA, Sherker AH. Reactivation of chronic hepatitis B infection related to imatinib mesylate therapy. Hepatol Int. 2008;2:498-9.

14 Walker EJ, Simko JP, Ko AH. Hepatitis B viral reactivation secondary to imatinib treatment in a patient with gastrointestinal stromal tumor. Anticancer Res. 2014;34:3629-34.

15 Inayat F, Song F, Ali NS, Aslam MH, Aloma A, Hachem H, et al. Hepatitis B virus reactivation following imatinib therapy: a comparative review of 9 cases. J Oncol Pharm Pract. 2019;25:1500-8.

16 Lai GM, Yan SL, Chang CS, Tsai CY. Hepatitis B reactivation in chronic myeloid leukemia patients receiving tyrosine kinase inhibitor. World J Gastroenterol. 2013;19:1318-21.

17 Shi Y, Zheng M. Hepatitis B virus persistence and reactivation. BMJ. 2020;370:m2200.

18 Bisceglie AMD, Lok AS, Martin P, Terrault N, Perrillo RP, Hoofnagle JH. Recent US Food and Drug Administration warnings on hepatitis B reactivation with immune-suppressing and anticancer drugs: just the tip of the iceberg? Hepatology. 2015;61:703-11.

19 Iqbal P, Soliman AT, Desanctis V, Yassin MA. Association of tuberculosis in patients with chronic myeloid leukemia, a treatment proposal based on literature review. Blood. 2020;136(Suppl 1):28-9. 